Eur J Clin Chem Clin Biochem

1995; 33:805-812

(c) 1995 Walter de Gruyter \& Co.

Berlin · New York

\title{
Time-Resolved Immunofluorometric Assay for the Quantification of Lipoprotein(a) in Serum
}

\author{
By Ulrich Missler ${ }^{1}$, Tilman Walek ${ }^{2}$ and Eduard Stange ${ }^{2}$ \\ ${ }^{1}$ Institut für Radiologie der Medizinischen Universität zu Lübeck, Lïbeck, Germany \\ ${ }^{2}$ Klinik für Innere Medizin der Medizinischen Universität zu Lübeck, Lübeck, Germany
}

(Received March 31/July 26, 1995)

Summary: Although two recent studies have failed to reveal lipoprotein(a) (LP(a)) serum concentrations $>300 \mathrm{mg} / \mathrm{l}$ to be an independent risk factor for early onset of atherosclerosis, $L p(a)$ serum concentrations are frequently measured to evaluate the additional risk of coronary heart disease. We describe a time-resolved immunofluorometric assay (TRIFMA) for quantifying $\mathrm{Lp}(\mathrm{a})$ levels in human serum using commercially available reagents, which is rapid, robust and simple to perform. The two-site immunometric assay was based on microtitre plates as solid phase coated with a polycloncal anti $\mathrm{Lp}(\mathrm{a})$ antibody. The liquid-phase antibody was labelled with biotin and detected by europium labelled streptavidin in the DELFIA 1232 fluorometer. The measuring range was $2-1600 \mathrm{mg} / \mathrm{l}$. The intra-assay imprecision was $<7 \%(\mathrm{CV})$, the inter-assay imprecision $<12 \%(\mathrm{CV})$. No interference was detected with plasminogen concentrations up to $2.2 \mathrm{~g} / \mathrm{l}$. There was an acceptable correlation with a commercially available enzyme immunoassay $(r=0.95)$ and with electroimmunodiffusion $(r=0.85)$ on 100 routine serum samples measured. The assay appeared to detect different $\mathrm{Lp}(\mathrm{a})$ isoforms as dilution curves were parallel for $\mathrm{B} / \mathrm{F}, \mathrm{S}_{2}$ and $\mathrm{S}_{4}$ isoforms.

\section{Introduction}

Numerous epidemiological and case-control studies have revealed lipoprotein(a) ( $\mathrm{Lp}(\mathrm{a}))$ serum concentrations $>300 \mathrm{mg} / \mathrm{l}$ to be an independent risk factor for myocardial infarction, stroke and restenosis after coronary artery bypass surgery (1-9). The results have been confirmed by a prospective study (10). Ridker et al. and Jauhiainen et al., however, could not show any correlation between $\mathrm{Lp}$ (a) serum levels and atherosclerosis (11, 12). Nevertheless, $L p(a)$ serum concentrations are frequently measured to estimate the additional risk of atherosclerotic disease.

$\left.\mathrm{Lp}(\mathrm{a})^{1}\right)$ is a cholesterol ester-rich lipoprotein which resembles $\mathrm{LDL}^{1}$ ) with the presence of apolipoprotein $\mathrm{B}$ -

\footnotetext{
1) Non-standard abbreviations:

Lp(a): lipoprotein(a); TRIFMA: time-resolved immunofluorometric assay; LDL: low density lipoprotein; IRMA: immunoradiometric assay; EIA: enzyme immunoassay; IEMA: immunoenzymometric assay.
}

100 to which the glycoprotein apolipoprotein(a) is covalently bound. Apolipoprotein(a) contains three structural regions, which are also present in plasminogen: variable numbers of kringle 4 , one kringle 5 and a protease domain (14). The number of kringle 4 repeats is a genetic trait and determines the relative molecular mass $\left(M_{\mathrm{r}}\right)$ polymorphism of apolipoprotein(a). In the Caucasian population the frequency distribution of $L p(a)$ serum concentration is markedly skewed with a shift toward lower levels. $\mathrm{Lp}(\mathrm{a})$ serum concentrations are inversely related to the size of apolipoprotein(a) isoforms and range from less than $1 \mathrm{mg} / 1$ to $>2000 \mathrm{mg} / 1$ (9).

Several analytical methods have been described to quantify $L p(a)$ levels in serum. Electroimmunodiffusion (EID) was followed by radioimmunoassay (RIA) and enzyme immunoassay (EIA) (16-20). Nephelometric techniques have recently been introduced to automate the $\operatorname{Lp}(\mathrm{a})$ determination $(21,22)$. These methods, however, are either difficult to perform in large series, time consuming, or lack accuracy and precision at low and 
high concentrations of $\mathrm{Lp}(\mathrm{a})$. The use of radioimmunoassays is restricted to authorised laboratories.

We describe a non-radioisotopic $\mathrm{Lp}(\mathrm{a})$ assay, which offers a wide measuring range, high sensitivity and low intra- and inter-assay imprecision. The assay is rapid, robust, simple to perform and suitable for routine use.

\section{Materials and Methods}

\section{Samples}

Serum was used as specimen throughout. The sera were measured either directly after centrifugation or after being stored frozen at $-20^{\circ} \mathrm{C}$. Samples to define the reference range were obtained from healthy blood donors. The plasma and serum samples for the comparison of measurement in plasma and serum were obtained from healthy employees of the hospital.

\section{Reagents}

All chemicals were analytical grade from Merck (Darmstadt, Germany) or Sigma (Deisenhofen, Germany), if not stated otherwise. We used double distilled water for all buffers and solutions.

\section{Buffers}

\section{Assay buffer}

Tris $0.05 \mathrm{~mol} / \mathrm{h}, \mathrm{NaCl} 0.15 \mathrm{~mol} / \mathrm{l}$, bovine serum albumin $5 \mathrm{~g} / 1$ (Sigma), bovine $\gamma$-globulin $0.5 \mathrm{~g} /$ (Sigma), diethylenetriaminepentaacetic acid (DTPA) $0.01 \mathrm{~mol} / 1$ (Sigma), $\mathrm{NaN}_{3} 0.15 \mathrm{mmol} / \mathrm{l}$, Tween $200.2 \mathrm{ml} / \mathrm{l}$ (Sigma), pH adjusted to 7.75 .

\section{Washing buffer}

Tris $0.05 \mathrm{~mol} / \mathrm{l}, \mathrm{NaCl} 0.15 \mathrm{~mol} / \mathrm{l}$, Tween $201 \mathrm{ml} / \mathrm{l}, \mathrm{pH}$ 7.5. The washing buffer was stored in a 40 -fold concentrate and was stable for half a year.

\section{Coating buffer}

$\mathrm{Na}_{2} \mathrm{CO}_{3} 0.05 \mathrm{~mol} / \mathrm{N}, \mathrm{NaHCO}_{3} 0.05 \mathrm{~mol} / \mathrm{l}, \mathrm{NaN}_{3} 0.15 \mathrm{mmol} / \mathrm{l}, \mathrm{pH}$ 9.6.

\section{Enhancement solution}

Citric acid $0.1 \mathrm{~mol} / \mathrm{l}$, tri-n-octyl-phosphine-oxide $0.01 \mathrm{~mol} / \mathrm{l}$, potassium-phthalate $0.08 \mathrm{~mol} / 1$ (Sigma), thenoyltrifluoroacetone 0.01 $\mathrm{mol} / \mathrm{l}$ (Sigma), Triton X-100 $2 \mathrm{ml} / \mathrm{l}$ (Sigma).

\section{Antibodies}

The polyclonal $\mathrm{Lp}(\mathrm{a})$ antibodies were purchased from DAKO (Hamburg, Germany), Code No. Q 023, Lot No. 062, and from Immuno GmbH (Heidelberg, Germany) Art. No. 4845009, Lot No. $2421 / 360$. The calibrator and the controls were from Immuno $\mathrm{GmbH}$, Art. No. 4395006 and Art No. 4395106, respectively.

Streptavidin was purchased from Biomol (Hamburg, Germany), the europium labelling reagent was from Pharmacia (Uppsala, Sweden), Art. No. 1244-301. Microtitre plates were from Nunc (Roskilde, Denmark), maxisorp F 96.

\section{Apparatus}

We used the Novopath Platewasher (Bio Rad, Munich, Germany), the Heidolph microtitre plate shaker (Heidolph, Kelheim, Ger- many), and the DELFIA 1232 time-resolved fluorometer from Pharmacia (Uppsala, Sweden).

\section{Assay procedure}

Microtitre plates were coated with $200 \mu$ per well of sheep anti Lp(a) antibody from Immuno (10 1 l diluted in $20 \mathrm{ml}$ coating buffer). Each plate was allowed to stand 'overnight at $4^{\circ} \mathrm{C}$, then the coating solution was aspirated, the plate washed once with washing buffer, and $200 \mu \mathrm{l}$ per well of assay buffer were added for storage.

Calibrators, controls and samples were diluted $1: 500$ in assay buffer. The calibrator containing $800 \mathrm{mg} / \mathrm{l} \mathrm{Lp(a)} \mathrm{was} \mathrm{diluted}$ $1: 250$ to give a final concentration of $1600 \mathrm{mg} / \mathrm{l}$. Twenty $\mu \mathrm{l}$ of the diluted calibrators, controls and samples were pipetted into each well, allowed to stand for 30 minutes at ambient temperature $\left(18-22^{\circ} \mathrm{C}\right)$ followed by $200 \mu \mathrm{l}$ assay buffer. After incubation for one hour on the microtitre plate shaker with $200 \mathrm{~min}^{-1}$ at ambient temperature, the plate was washed three times with washing buffer.

Tab. 1 Influence of haemolysis on the $L p(a)$ concentrations measured with the Lp(a) TRIFMA. Ten serum samples were measured directly and after mechanical treatment to produce haemolysis. On the right the haemoglobin concentration in the sera after haemolysis is given. The coefficient of correaltion for the $L p(a)$ concentrations before and after haemolysis was $\mathrm{r}=0.998$.

\begin{tabular}{|c|c|c|c|}
\hline \multirow{2}{*}{$\begin{array}{l}\text { Sample } \\
\text { no. }\end{array}$} & \multicolumn{2}{|c|}{$\mathrm{Lp}(\mathrm{a})$ concentration } & \multirow{2}{*}{$\begin{array}{l}\text { Haemoglobin } \\
\text { concentration }\end{array}$} \\
\hline & $\begin{array}{l}\text { before } \\
\text { haemolysis } \\
{[\mathrm{mg} / \mathrm{l}]}\end{array}$ & $\begin{array}{l}\text { after } \\
\text { haemolysis } \\
{[\mathrm{mg} / \mathrm{l}]}\end{array}$ & \\
\hline 1 & 60 & 57 & 1.2 \\
\hline 2 & 420 & 390 & 1.4 \\
\hline 3 & 620 & 600 & 1.8 \\
\hline 4 & 260 & 270 & 1.9 \\
\hline 5 & 9.9 & 9.0 & 1.6 \\
\hline 6 & 440 & 450 & 1.2 \\
\hline 7 & 590 & 605 & 1.1 \\
\hline 8 & 16 & 14 & 1.4 \\
\hline 9 & 245 & 238 & 1.3 \\
\hline 10 & 58 & 55 & 1.9 \\
\hline
\end{tabular}

Tab. 2 Influence of triacylglycerol concentrations on the $\mathrm{Lp}(\mathrm{a})$ concentrations measured with the Lp(a) TRIFMA. One sample containing high level of $\mathrm{Lp}(\mathrm{a})(496 \mathrm{mg} / \mathrm{l})$ and low level of triacylglycerol $(0.3 \mathrm{mmol} / \mathrm{l})$ was mixed with another sample with low Lp(a) concentration $(47 \mathrm{mg} / \mathrm{l})$ and high level of triacylglycerol (15.7 mmol/l). No influence of triacylglycerol concentration on the $\mathrm{Lp}$ (a) concentrations can be observed.

\begin{tabular}{|c|c|c|c|}
\hline \multicolumn{2}{|c|}{ Fraction of } & \multicolumn{2}{|c|}{$\mathrm{Lp}$ (a) concentration $[\mathrm{mg} / 1]$} \\
\hline sample 1 & sample 2 & Measured & Expected \\
\hline 1.00 & 0 & 496 & 496 \\
\hline 0.90 & 0.10 & 447 & 451 \\
\hline 0.80 & 0.20 & 387 & 406 \\
\hline 0.70 & 0.30 & 344 & 361 \\
\hline 0.60 & 0.40 & 294 & 316 \\
\hline 0.50 & 0.50 & 246 & 272 \\
\hline 0.40 & 0.60 & 203 & 227 \\
\hline 0.30 & 0.70 & 168 & 182 \\
\hline 0.20 & 0.80 & 122 & 137 \\
\hline 0.10 & 0.90 & 86 & 92 \\
\hline 0 & 1.00 & 47 & 47 \\
\hline
\end{tabular}


Two-hundred $\mu$ l of DAKO anti Lp(a) antibody which had been labelled with biotin as described previously $(26)$ and diluted in assay buffer to a final concentration of $1 \mathrm{mg} / \mathrm{l}$ were incubated for another hour (ambient temperature, $200 \mathrm{~min}^{-1}$ ). After washing three times with washing buffer, $200 \mu l$ of the streptavidin europium conjugate in assay buffer were added to each well and incubated for 30 minutes (ambient temperature, $200 \mathrm{~min}^{-1}$ ). Streptavidin was labelled as recommended by Pharmacia (Uppsala, Sweden)

Tab. 3 Lp(a) levels in serum, heparin-, citrate- and EDTA-plasma of 20 healthy hospital employees. The coefficients of correlation for serum vs. citrate-plasma was $r=0.994$, for serum vs. heparinized plasma $r=0.998$, for serum vs. EDTA-plasma $r=0.999$, respectively. (*Dilution effect of 1:10 must be taken into consideration. These were the measured concentrations.)

\begin{tabular}{lllll}
\hline $\begin{array}{l}\text { Sample } \\
\text { no. }\end{array}$ & $\begin{array}{l}\text { Lp(a) con- } \\
\text { centration } \\
{[\mathrm{mg} / 1]}\end{array}$ & $\begin{array}{l}\text { Lp(a) con- } \\
\text { centration } \\
\text { [mg/l]* }\end{array}$ & $\begin{array}{l}\text { Lp(a) con- } \\
\text { centration } \\
\text { [mg/l] }\end{array}$ & $\begin{array}{l}\text { Lp(a) con- } \\
\text { centration } \\
\text { [mg/l] }\end{array}$ \\
& Serum & $\begin{array}{l}\text { Citrate- } \\
\text { plasma }\end{array}$ & $\begin{array}{l}\text { Heparin- } \\
\text { plasma }\end{array}$ & $\begin{array}{l}\text { EDTA- } \\
\text { plasma }\end{array}$ \\
\hline 1 & & 46 & 50 & 51 \\
2 & 143 & 124 & 94 & 134 \\
3 & 22 & 20 & 21 & 15 \\
4 & 71 & 60 & 60 & 63 \\
5 & 100 & 78 & 96 & 111 \\
6 & 33 & 27 & 34 & 30 \\
7 & 25 & 23 & 28 & 26 \\
8 & 19 & 17 & 15 & 17 \\
9 & 12 & 14 & 14 & 13 \\
10 & 360 & 260 & 300 & 330 \\
11 & 130 & 110 & 100 & 110 \\
12 & 22 & 20 & 22 & 23 \\
13 & 9 & 9 & 8 & 8 \\
14 & 59 & 46 & 52 & 58 \\
15 & 1400 & 1560 & 1200 & 1240 \\
16 & 267 & 257 & 296 & 285 \\
17 & 31 & 27 & 29 & 33 \\
18 & 320 & 230 & 290 & 290 \\
19 & 16 & 13 & 13 & 19 \\
20 & 43 & 33 & 38 & 34 \\
\hline
\end{tabular}

Tab. 4 Influence of storing conditions of $\mathrm{Lp}$ (a) measurement. Ten serum samples stored at $4{ }^{\circ} \mathrm{C}$ and frozen at $-20^{\circ} \mathrm{C}$ for 21 days, respectively. Another ten samples have been stored at $4^{\circ} \mathrm{C}$ and at $-80^{\circ} \mathrm{C}$ for the same time. The coefficients of correlation for $\mathrm{Lp}(\mathrm{a})$ concentrations measured in samples stored at $4^{\circ} \mathrm{C}$ vs. samples stored at $-20^{\circ} \mathrm{C}$ was $\mathrm{r}=0.996$, for samples stored at $4^{\circ} \mathrm{C}$ vs. $-80^{\circ} \mathrm{C} \mathrm{r}=0.990$, respectively.

\begin{tabular}{|c|c|c|c|c|c|}
\hline \multirow{3}{*}{$\begin{array}{l}\text { Sam- } \\
\text { ple } \\
\text { no. }\end{array}$} & \multicolumn{2}{|c|}{ Storing at } & \multirow{3}{*}{$\begin{array}{l}\text { Sam- } \\
\text { ple } \\
\text { no. }\end{array}$} & \multicolumn{2}{|c|}{ Storing at } \\
\hline & $4^{\circ} \mathrm{C}$ & $-20^{\circ} \mathrm{C}$ & & $4^{\circ} \mathrm{C}$ & $-80^{\circ} \mathrm{C}$ \\
\hline & $\begin{array}{l}\mathrm{Lp}(\mathrm{a}) \\
{[\mathrm{mg} / \mathrm{i}]}\end{array}$ & $\begin{array}{l}\mathrm{Lp}(\mathrm{a}) \\
{[\mathrm{mg} / 1]}\end{array}$ & & $\begin{array}{l}\mathrm{L} \cdot \mathrm{p}(\mathrm{a}) \\
{[\mathrm{mg} / \mathrm{l}]}\end{array}$ & $\begin{array}{l}\mathrm{Lp}(\mathrm{a}) \\
{[\mathrm{mg} / \mathrm{I}]}\end{array}$ \\
\hline 1 & 32 & 26 & 11 & 379 & 417 \\
\hline 2 & 110 & 130 & 12 & 197 & 201 \\
\hline 3 & 451 & 426 & 13 & 490 & 570 \\
\hline 4 & 40 & 33 & 14 & 34 & 31 \\
\hline 5 & $>1600$ & $>1600$ & 15 & 116 & 139 \\
\hline 6 & 14 & 14 & 16 & 83 & 93 \\
\hline 7 & 747 & 671 & 17 & 40 & 39 \\
\hline 8 & 984 & 836 & 18 & 155 & 163 \\
\hline 9 & 24 & 21 & 19 & 35 & 32 \\
\hline 10 & 387 & 358 & 20 & 257 & 216 \\
\hline
\end{tabular}

using their europium labelling reagent and diluted to a final concentration of $0.025 \mathrm{mg} / \mathrm{l}$. After a final washing step $200 \mu \mathrm{l}$ enhancement solution were added to each well and then incubated for 30 minutes (ambient temperature, $200 \mathrm{~min}^{-1}$ ). The plate was measured in the DELFIA 1232 fluorometer. The calibration curve was constructed using a modified spline function in the FIA-Calc data reduction programme of the DELFIA 1232 system after a log/ $\log$ transformation of the data.

\section{Influence of haemolysis}

To investigate the influence of haemolysis 10 blood samples were divided into two aliquots each. One was immediately centrifuged and the serum measured. The other was mechanically haemolysed on a tube shaker. All samples were macroscopically haemolytic after this procedure. The haemoglobin concentration after centrifugation was between 1 and $2 \mathrm{~g} / \mathrm{l}$, as measured with the cyanmethaemoglobin method (tab. 1).

Tab. 5 Stability of the coated $\mathrm{Lp}$ (a) microtitre plate stored for 3 months in assay buffer at $4^{\circ} \mathrm{C}$. Given are the calibrator concentrations, the response and the concentrations of 3 control sera measured with plates prepared 1 week and 13 weeks before. (* Assay date for both plates was 7. Feb. 1995.)

\begin{tabular}{llr}
\hline $\begin{array}{l}\text { Calibrator } \\
\text { concentration } \\
\text { [mg/l] }\end{array}$ & \multicolumn{2}{l}{ Response [counts/s]* } \\
\cline { 2 - 3 } & $\begin{array}{l}\text { Plate coated } \\
\text { 28. Oct. 1994 }\end{array}$ & $\begin{array}{c}\text { Plate coated } \\
\text { 6. Feb. 1995 }\end{array}$ \\
\hline 2 & 9071 & 9440 \\
10 & 30414 & 32016 \\
50 & 118040 & 122472 \\
200 & 365959 & 388782 \\
800 & 877622 & 968806 \\
1600 & 1207095 & 1209315 \\
\hline & Concentration [mg/l] \\
\hline Control 1 & 187 & 190 \\
Control 2 & 378 & 345 \\
Control 3 & 683 & 715 \\
\hline
\end{tabular}

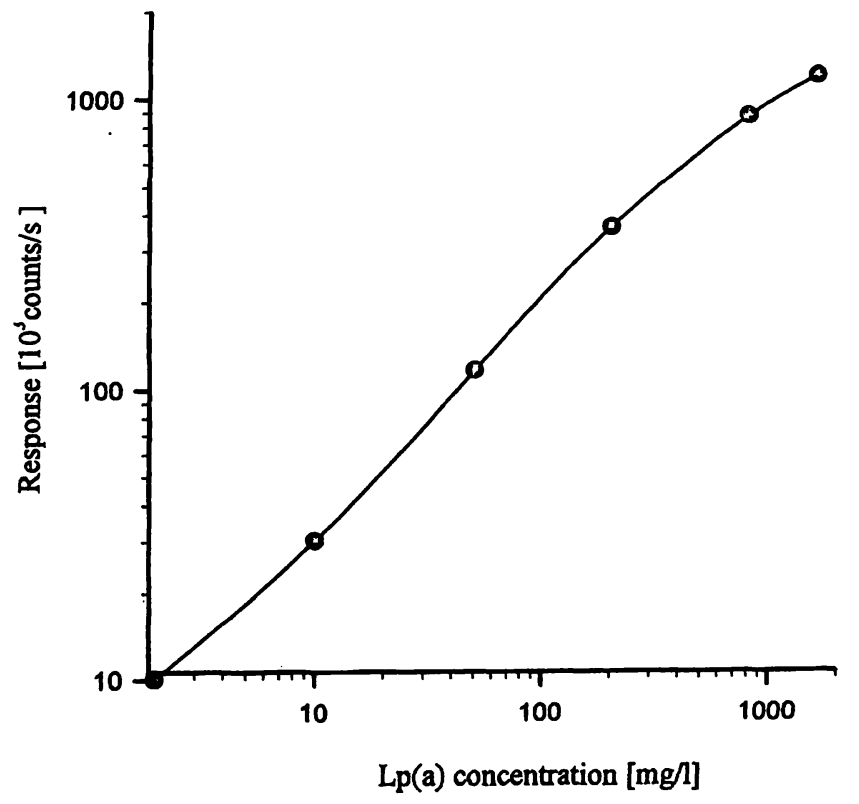

Fig. 1 Calibration curve of the Lp(a) TRIFMA after $\log / \log$ transformation of the data. 
Tab. 6 Analytical recovery of the Lp(a) TRIFMA. Eighteen serum samples were mixed $1+1$ (by vol.) with a serum containing $950 \mathrm{mg} / \mathrm{l} \mathrm{Lp}(\mathrm{a})$. The analytical recovery was calculated in percent.

\begin{tabular}{|c|c|c|c|c|c|}
\hline $\begin{array}{l}\text { Sample } \\
\text { no. }\end{array}$ & $\begin{array}{l}\text { Serum } \mathrm{Lp}(\mathrm{a}) \\
\text { concentration } \\
{[\mathrm{mg} / \mathrm{ll}]}\end{array}$ & $\begin{array}{l}\text { Added concentration } \\
{[\mathrm{mg} / \mathrm{l}]}\end{array}$ & $\begin{array}{l}\text { Expected value } \\
{[\mathrm{mg} / \mathrm{l}]}\end{array}$ & $\begin{array}{l}\text { Measured value } \\
{[\mathrm{mg} / \mathrm{l}]}\end{array}$ & $\begin{array}{l}\text { Recovery } \\
{[\%]}\end{array}$ \\
\hline 1 & 403 & 950 & 675 & 675 & 100 \\
\hline 2 & 201 & 950 & 575 & 598 & 102 \\
\hline 3 & 100 & 950 & 525 & 501 & 95 \\
\hline 4 & 7 & 950 & 478 & 429 & 87 \\
\hline 5 & 640 & 950 & 507 & 503 & 99 \\
\hline 6 & 995 & 950 & 973 & 1016 & 104 \\
\hline 7 & 7 & 950 & 478 & 427 & 89 \\
\hline 8 & 108 & 950 & 500 & 542 & 108 \\
\hline 9 & 543 & 950 & 745 & 378 & 99 \\
\hline 10 & 241 & 950 & 595 & 564 & 95 \\
\hline 11 & 10 & 950 & 480 & 453 & 94 \\
\hline 12 & 77 & 950 & 510 & 486 & 95 \\
\hline 13 & 52 & 950 & 501 & 457 & 91 \\
\hline 14 & 8 & 950 & 479 & 479 & 100 \\
\hline 15 & 298 & 950 & 624 & 613 & 98 \\
\hline 16 & 389 & 950 & 669 & 633 & 95 \\
\hline 17 & 204 & 590 & 575 & 606 & 106 \\
\hline 18 & 19 & 950 & 480 & 448 & 93 \\
\hline
\end{tabular}

\section{Influence of lipaemia}

To investigate the influence of hypertriacylglycerolaemia 2 samples were mixed with each other in steps of $10 \%$. Sample 1 contained $496 \mathrm{mg} / \mathrm{Lp}(\mathrm{a})$ and $0.3 \mathrm{mmol} / \mathrm{l}$ triacylglycerols as determined in the routine laboratory. Sample 2 contained $47 \mathrm{mg} / \mathrm{l} \mathrm{Lp}(\mathrm{a})$ and $15.7 \mathrm{mmol} / \mathrm{l}$ triacylglycerols, respectively (tab. 2).

\section{Interference of plasminogen}

To assess the interference of plasminogen on the assay purified plasminogen (Sigma) was diluted in assay buffer to give final concentrations of $0.1 ; 2.2 ; 22 ; 220$ and $2200 \mathrm{mg} / \mathrm{l}$, respectively and measured in the assay. All concentrations were below the lowest calibrator $(0.06 ; 0.26 ; 1.1 ; 0.6$ and $1.4 \mathrm{mg} / \mathrm{l}$, respectively). Even when measured without the obligate predilution corresponding to a theoretical, original concentration of $1100 \mathrm{~g} / 1(!)$ only $16 \mathrm{mg} / \mathrm{l}$ were detected.

\section{Measurement in serum and different kinds of plasma}

To evaluate the effect of measuring $L p(a)$ in different derivatives from blood, blood from 20 healthy employees of the hospital was obtained as serum, heparinized plasma, EDTA-plasma and citrateplasma. Results are given in table 3.

\section{Effect of storing conditions on $L p(a)$ levels}

To assess the influence of storing conditions on the stability of $\mathrm{Lp}$ (a) 10 serum samples were stored at $4^{\circ} \mathrm{C}$ and $-20^{\circ} \mathrm{C}$ for 21 days. Another 10 samples were stored at $4{ }^{\circ} \mathrm{C}$ and $-80^{\circ} \mathrm{C}$ for the same period (tab. 4). The effect of repeated freeze and thaw cycles was not investigated, because the negative influence is well known.

\section{Stability of coated microtitre plates}

To evaluate the stability of the coated microtitre plates one plate was stored for 13 weeks in assay buffer at $4{ }^{\circ} \mathrm{C}$ and compared with a plate coated one week before (tab. 5).

\section{Electroimmunodiffusion (EID)}

Electroimmunodiffusion was performed in a $1 \mathrm{~mm}$, anti $\mathrm{Lp}(\mathrm{a})$ antiserum containing agarose gel with a LKB-Multiphor II electrophoresis unit (LKB-Pharmacia, Uppsala, Sweden) as described recently $(16,23)$.

\section{Enzyme immunoassay (EIA)}

To quantify Lp(a) by EIA, the IMMUNOZYM Lp(a) EIA kit from Immuno GmbH (Heidelberg, Germany) was used following the manufacturers recommendations. This kit uses a monospecific, polyclonal anti apolipoprotein(a) antibody on the solid-phase, and a peroxidase labelled, monoclonal anti apolipoprotein(a) antibody for detection (figs. 3 and 4).

\section{Influence of apolipoprotein(a) isoforms on $\mathrm{Lp}(\mathrm{a})$ measurement}

To investigate, whether the TRIFMA measures irrespective of different isoforms of apolipoprotein(a), sera containing apolipoprotein(a) isoforms $\mathrm{B} / \mathrm{F}, \mathrm{S}_{2}$ and $\mathrm{S}_{4}$ (determined as described by Laemmli (29)) were measured after serial dilution in assay buffer (Fig. 5).

\section{Measurement in triacylglycerol-rich fraction}

To test $\mathrm{Lp}$ (a) measurement in triacylglycerol-rich fraction of serum, sera were ultracentrifuged at $30000 \mathrm{~min}^{-1}$ for 18 hours and

Tab. 7 Intra-assay and inter-assay imprecision of the $L p(a)$ TRIFMA.

\begin{tabular}{llll}
\hline $\begin{array}{l}\text { Mean con- } \\
\text { centration } \\
{[\mathrm{mg} / \mathrm{l}]}\end{array}$ & $\begin{array}{l}\text { Intra-assay } \\
\text { imprecision } \\
\text { CV [\%] }\end{array}$ & $\begin{array}{l}\text { Mean con- } \\
\text { centration: } \\
{[\mathrm{mg} / \mathrm{l}]}\end{array}$ & $\begin{array}{l}\text { Inter-assay } \\
\text { imprecision } \\
\text { CV [\%] }\end{array}$ \\
\hline $61(\mathrm{n}=20)$ & 2.81 & $49(\mathrm{n}=22)$ & 11.5 \\
$372(\mathrm{n}=20)$ & 4.10 & $193(\mathrm{n}=22)$ & 6.64 \\
$932(\mathrm{n}=20)$ & 6.77 & $776(\mathrm{n}=22)$ & 9.83 \\
\hline
\end{tabular}


the supernatant and the remaining serum fraction measured separately after serial dilution in assay buffer (fig. 6 ).

\section{Statistical analyses}

The correlation of $L p(a)$ levels between TRIFMA, EID and EIA, was calculated using a non-parametric linear regression analysis as described by Passing \& Bablock (30). In the legends to the figures 2,3 and 4 the coefficient of correlation (r), the equation formula of the regression analysis $(y=a+b x)$, the result of the Cusum test for deviation from linearity (significant or not significant) and the result of the test for contingency (p-values) are given. To prove the data in tables 1, 3 and 4 statistically, the coefficient of correlation was calculated, instead of a statistical test, because of the low number of data pairs.

\section{Results}

\section{Assay characteristics}

Figure 1 shows a typical calibration curve for the $L p(a)$ TRIFMA. The potential lower detection limit was 0.39 $\mathrm{mg} / \mathrm{l}$, calculated as the response of the zero calibrator (assay buffer) $+3 \mathrm{SD}(\mathrm{n}=20)$. The measuring range was 2-1600 mg/l. A high dose "hook" effect was not detectable up to $5000 \mathrm{mg} / 1$ (response for the $1600 \mathrm{mg} / \mathrm{l}$ calibrator: 1014527 counts/s, response for $5000 \mathrm{mg} / \mathrm{l}$ : 1689754 counts/s). Analytical recovery ranged from 87 to $108 \%$ (tab. 6). The intra-assay imprecision was $<7 \%$ $(\mathrm{CV}, \mathrm{n}=20)$, the inter-assay imprecision was $<12 \%$ $(\mathrm{CV}, \mathrm{n}=22)(\mathrm{tab} .7)$.

To calculate the reference range of $L p(a)$ in this assay, specimens from 88 healthy blood donors were measured. There is a wide range of $\mathrm{Lp}(\mathrm{a})$ levels in healthy individuals which does not follow a Gaussian distribu-

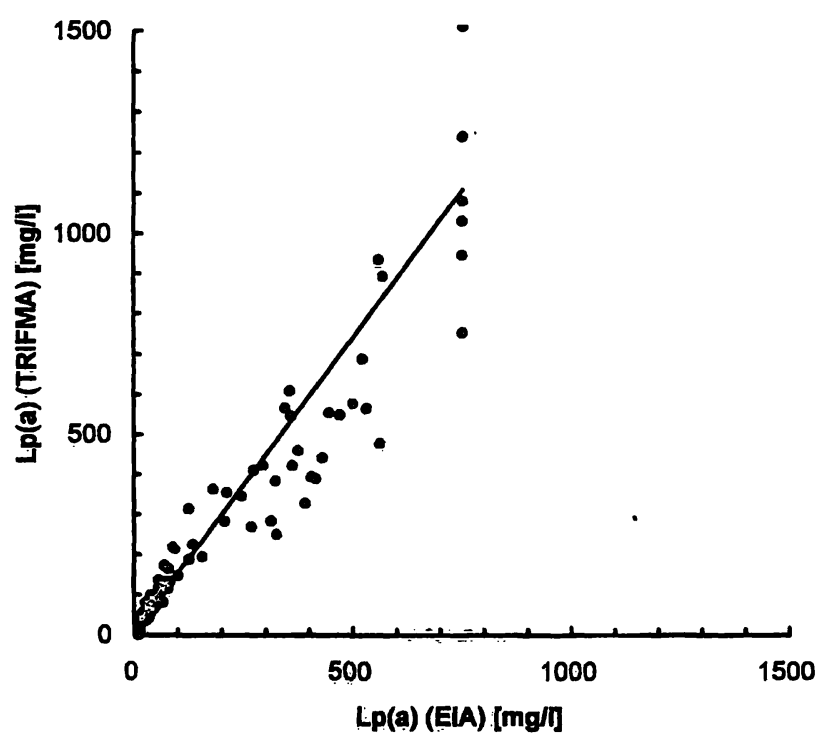

Fig. 2 Plot of the regression analyșis of $L p(a)$ serum levels as determined by enzyme immunoassay (EIA $=x$ ) and time-resolved immunofluorometric assay (TRIFMA $=y)(r=0.95 ; y=1.47 x$ + 766; as described by Passing \& Bablok, Cusum test on deviation from linearity: not significant, test for contingency: $p=0.003$, $\mathrm{n}=100$ ). tion, as previously described (13). Thus, we calculated the median, the $75^{\text {th }}, 90^{\text {th }}$ and $95^{\text {th }}$ percentile instead of the arithmetic mean. The median of the 88 samples was $99 \mathrm{mg} / \mathrm{l}$, which corresponds well with the literature (24), the $75^{\text {th }}$ percentile was $362 \mathrm{mg} / \mathrm{l}$, the $90^{\text {th }} 569 \mathrm{mg} / \mathrm{l}$ and the $95^{\text {th }} 670 \mathrm{mg} / \mathrm{l} \mathrm{Lp}(\mathrm{a})$, respectively. There was no interference with plasminogen detectable up to a plasminogen concentration of $2.2 \mathrm{~g} / 1$ (10 fold above the upper limit of the reference range) and no interference with lipaemic or haemolytic samples, either (tabs. 1 and 2).

The Lp(a) TRIFMA was compared with the EIA from Immuno and the electroimmunodiffusion technique. The results of the TRIFMA correlated highly with the EIA $(r=0.95 ; y=1.47 x+7.66$, Cusum test on deviation from linearity: not significant, test for contingency: $\mathrm{p}=0.003, \mathrm{n}=100$; fig. 2). Differences were seen in low $(<40 \mathrm{mg} / \mathrm{l})$ and high concentrations $(>450 \mathrm{mg} / \mathrm{l})$. The correlation between the results of the TRIFMA and the electroimmunodiffusion assay (EID) was not as good as the latter, probably because of the better linearity of the TRIFMA over a wide measuring range $(r=0.85$; $y=1.38 x-69.7$; Cusum test on deviation from linearity: not significant, test for contingency: $p=0.308$, $\mathrm{n}=100$; fig. 3 ). This conjecture is supported by the better correlation between EIA and EID $(r=0.92$; $y=0.98 x-61.6$; Cusum test on deviation from linearity: not significant, test for contingency: $p=0.065$, $\mathrm{n}=100$; fig. 4).

Figure 5 shows the influence of different apolipoprotein(a) isoforms on the $L p(a)$ measurement with the $\mathrm{Lp}$ (a) TRIFMA. The distribution of $\mathrm{Lp}(\mathrm{a})$ between the

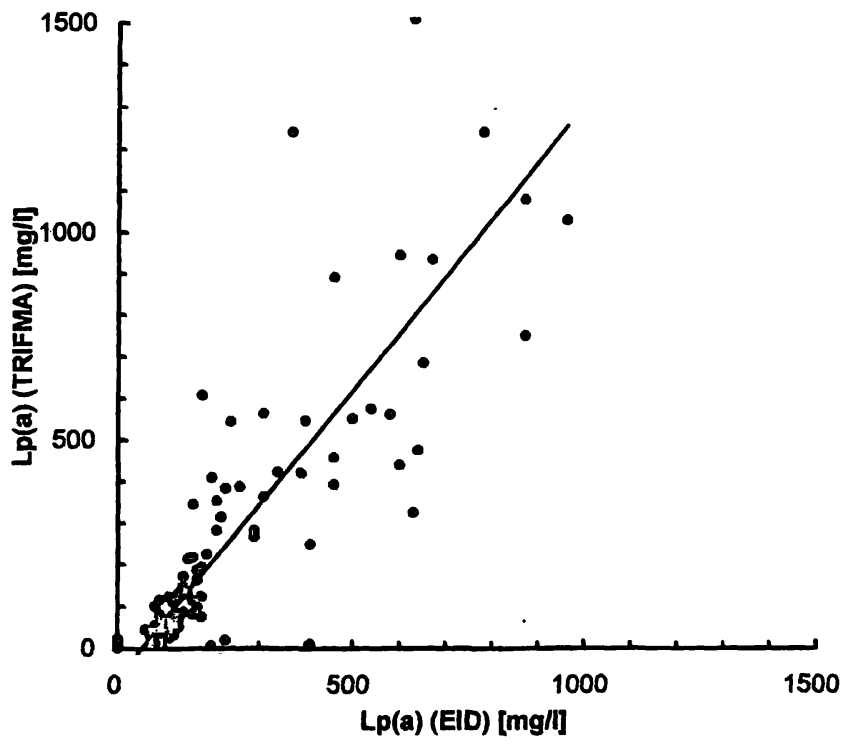

Fig. 3 Plot of the regression analysis of $L p$ (a) serum levels [mg/l] as determined by electroimmunodiffusion (EID $=x$ ) and time-resolved immunofluorometric assay (TRIFMA $=y)(r=0.85$; $y=1.28 x-69.7$; as described by Passing \& Bablok, Cusum test on deviation from linearity: not significant, test for contingency: $p=0.308, n=100$ ). 


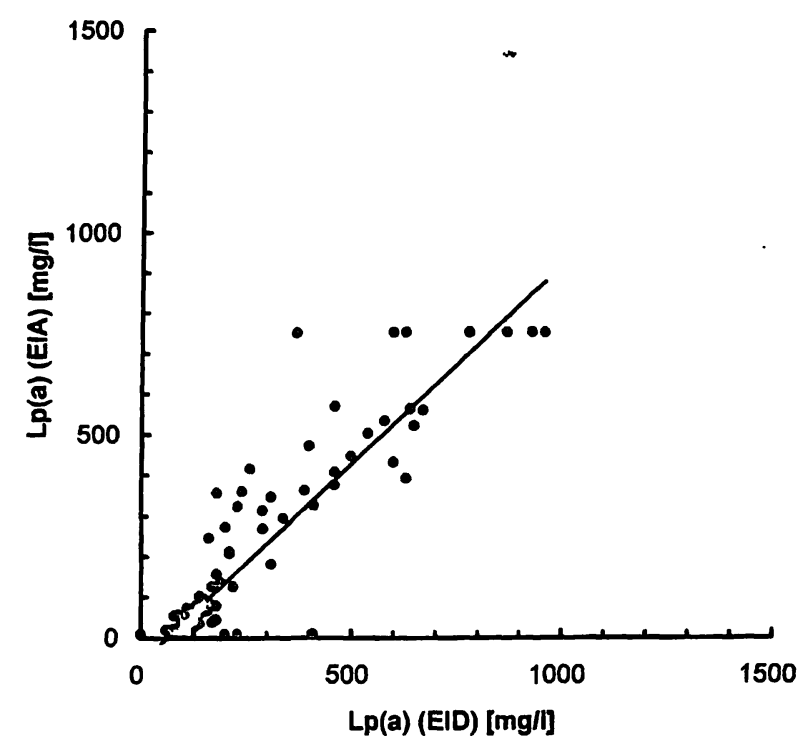

Fig. 4 Plot of the regression analysis of $L p(a)$ serum levels as measured by electroimmunodiffusion (EID $=x$ ) and enzyme immunoassay (EIA $=y)(r=0.92 ; y=0.98 x-61.6$; as described by Passing \& Bablok, Cusum test on deviation from linearity: not significant, test for contingency: $p=0.065$, $\mathrm{n}=100$ ).

supernatant and the remaining fluid after ultracentrifugation is shown in figure 6.

\section{Discussion}

Numerous investigations have revealed $\mathrm{Lp}(\mathrm{a})$ to be a genetically determined, independent risk factor for coronary heart disease, cerebrovascular disease and peripheral arterial occlusion (1-9) although two studies, however, have failed to confirm these results $(11,12)$. Lp(a) serum levels are quantified routinely with different analytical methods.

Electroimmunodiffusion (EID) is often referred to as the "standard" method to measure $\operatorname{Lp}(a)(15,16)$ and has been used to investigate $\mathrm{Lp}(\mathrm{a})$ in many studies. It is a simple and robust method, which is on the one hand not sensitive enough to detect low levels of $\mathrm{Lp}(\mathrm{a})$ and on the other hand not suitable for measuring large numbers of samples. Only 25 samples can be applied per gel and it takes two days until results are available. The nephelometric and turbidimetric assays can be completely automated using modern nephelometers but difficulties can arise with lipaemic or haemolytic sera (13). Furthermore, $L p(a)$ with its inverse relation between particle size and serum concentration is not the most suitable analyte for these techniques. These problems do not occur in sandwich immunoassays using either enzyme linked or radiolabelled antibodies for detection. Immunoradiometric assays (IRMA) and immunoenzymometric assays (IEMA) show excellent sensitivity and speci-

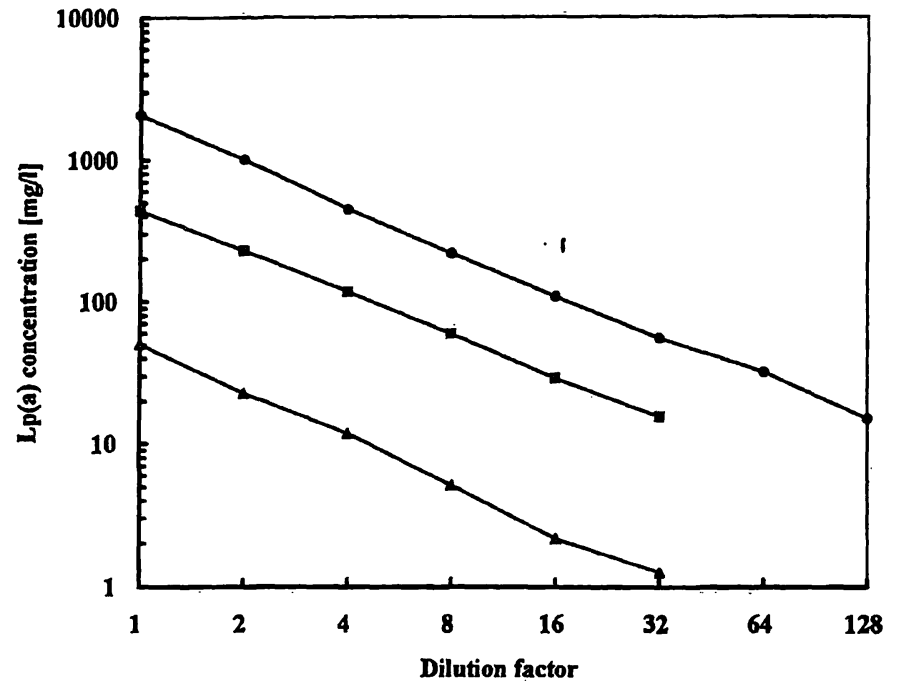

Fig. 5 Influence of different apolipoprotein(a) isoforms on the $L p(a)$ measurement with the $L p(a)$ TRIFMA. Three sera were serially diluted in assay buffer and $L p(a)$ concentrations were measured. Serum 1 (०) had a $\mathrm{Lp}$ (a) concentration of $2000 \mathrm{mg} / \mathrm{l}$, the apolipoprotein(a) isoform was determined as B/F, serum 2 (ש) had a $\mathrm{Lp}$ (a) concentration of $440 \mathrm{mg} / \mathrm{l}$, apolipoprotein(a) isoform was $\mathrm{S}_{2}$, serum $3(\Delta)$ contained $50 \mathrm{mg} / \mathrm{l} \mathrm{Lp}(\mathrm{a})$ and apolipoprotein(a) isoform $\mathrm{S}_{4}$.

fity (16-20). They are capable of assaying large numbers of samples. The use of radiolabelled substances, however, limits the suitability of such methods for routine laboratory application.

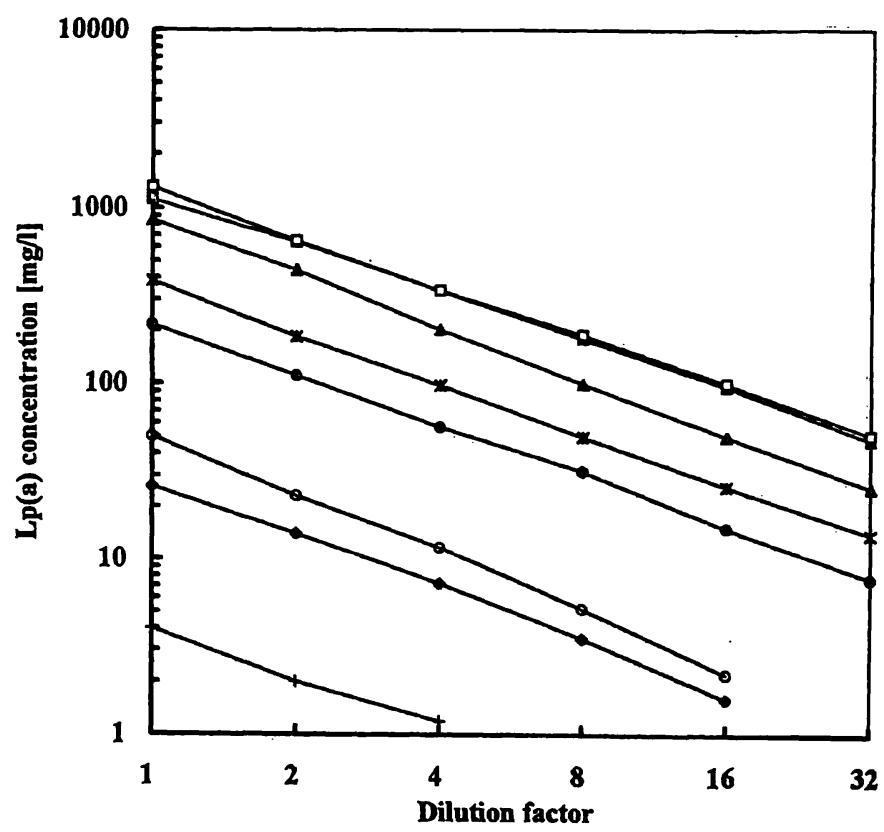

Fig. 6 Four sera were ultracentrifuged at $30000 \mathrm{~min}^{-1}$ for 18 hours. The supernatant containing the triacylglycerol-rich fraction was separated and the supernatant and the remaining serum were separately measured in the Lp(a) TRIFMA after serial dilution in assay buffer. Serum I contained $26 \mathrm{mg} / \mathrm{l} \mathrm{Lp}(\mathrm{a})$ in the supernatant $(\diamond)$ and $4 \mathrm{mg} / \mathrm{l}$ in the remaining fluid (+), serum II contained 848 $\mathrm{mg} / \mathrm{l}(\Lambda)$ and $384 \mathrm{mg} / \mathrm{l}(*)$, serum III $1110 \mathrm{mg} / \mathrm{l}(\mathbf{D})$ and $1307 \mathrm{mg} / 1$ $(\square)$ and serum IV $216 \mathrm{mg} / \mathrm{l}(\bullet)$ and $50 \mathrm{mg} / \mathrm{l}(0)$, respectively. 
Our data show, that $\operatorname{Lp}(\mathrm{a})$ has been stable for at least 3 weeks at $4^{\circ} \mathrm{C},-20^{\circ} \mathrm{C}$ and $-80^{\circ} \mathrm{C}$ (tab. 4). The calibrators and controls have been stored for 2 years at $-80^{\circ} \mathrm{C}$ without any loss of immunoreactivity. This is in agreement with the experience of other investigators ((23) and Wood, personal communication). Therefore, we cannot support the experience of Craig et al. (27) as far as twosite immunometric assays are concerned. The effect of freezing and thawing has been described previously (28).

The different immunoreactivity of the $L p(a)$ isoforms remains a problem in $L p(a)$ quantification. In our studies dilution experiments with samples containing different apolipoprotein(a) isoforms showed linear dilution curves irrespective of the apolipoprotein(a) isoform, when measured with our method. Thus, it can be concluded, that the TRIFMA measures $L p(a)$ independently of apolipoprotein(a) isoforms. This may be explained by the use of two polyclonal antibodies in this assay. Furthermore, dilution experiments after separating the triacylglycerolrich fraction of serum and measuring both fractions separately showed linear and parallel dilution curves in different $L p$ (a) concentration ranges irrespective of the serum fraction (fig. 6). These data suggest, that the TRIFMA can also measure free apolipoprotein(a). This can, however not be proved exactly due to lack in availability of free apolipoprotein(a), although both antibodies are directed against apolipoprotein(a) and not $L p(a)$.

The assay described here offers some advantages over other methods for $\mathrm{Lp}(\mathrm{a})$ quantification. In contrast to a similar assay described recently (23), we used the biotin streptavidin system with europium labelled streptavidin for the detection of the second antibody. Jürgens et al. (23) labelled their polyclonal anti apolipoprotein B or anti $L p(a)$ antibodies directly with europium. However, this is expensive because of the high price of the europium labelling reagent. Biotinylation of the antibody and europium labelling of streptavidin reduces the cost, be- cause biotin is cheap and every labelled streptavidin molecule can, at least in theory, react specifically with biotin.

Our method was not affected by triacylglycerols (tab. 2) or haemolysis (tab. 1). The interference of plasminogen was neglegible (s. results). The assay offers a wide measuring range and a lower detection limit, which is satisfactory for both clinical and research purposes. The accuracy and the easy and rapid performance make the method well suited for routine use.

Even if there is still some discussion about the clinical validity of $L p(a)$, this analyte is frequently measured. No "gold standard" exists for quantifying $\operatorname{Lp}(a)$. In this paper we describe a method, which exclusively makes use of commercially available reagents and which includes the biotin steptavidin system. Therefore this assay can be performed in many laboratories, e. g. with use of streptavidin-enzyme or -isoluminol labelling, reagents which are both commercially available.

We compared the TRIFMA (25) with an EIA and with the EID-method and found a good correlation with both methods (figs. 2 and 3). Differences, however, were seen at low and high concentrations of $\operatorname{Lp}(\mathrm{a})$. This can be explained by the superior ability of the TRIFMA to detect low and high $\mathrm{Lp}(\mathrm{a})$ levels. The $\mathrm{Lp}(\mathrm{a})$ assay described here has been successfully used as routine method for quantifying $L p(a)$ in our laboratory for more than $1 \frac{1}{2}$ years.

\section{Acknowledgements}

We thank Mrs. C. Solis-Perez for her excellent technical assistance and help in developing and evaluating the method, Mr. M. Grosu for the help in calculating statistics with the method described by Passing \& Bablok. And we thank Prof. Assmann and his laboratory staff, Münster, Germany, for $\mathrm{Lp}$ (a) quantification by electroimmunodiffusion. Special thank is addressed to Prof. W. G. Wood, Stralsund, Germany for reviewing the manuscript, for supplying different $\mathrm{Lp}$ (a) sera and for the many helpful comments.

\section{References}

1. Utermann G. Lipoprotein (a): a genetic risk factor for premature coronary heart disease. Curr Opin Lipidol 1990; 1:40410.

2. Armstrong VW, Cremer P, Eberle E, Manke A, Schulze F, Wieland $H$, et al. The association between serum $L p(a)$ concentrations and angiographically assessed coronary atherosclerosis - dependence on serum LDL levels. Atherosclerosis 1986; 62:249-57.

3. Sandkamp M, Funke H, Schulte $H$, Köhler E, Assmann G. Lipoprotein (a) is a independent risk factor for myocardial infarction at a young age. Clin Chem 1990; 36(1):20-3.

4. Loscalzo J. Lipoprotein (a). A unique risk factor for atherothrombotic disease. Atherosclerosis 1990; 10:671-9.

5. Scanu AM. $\mathrm{Lp}(\mathrm{a})$ as a marker of coronary heart disease. Clin Cardiol 1991; 14:35-9.

6. Sandholzer C, Saha N, Kark JD, Rees A, Jaross W, Dieplinger $\mathrm{H}$, et al. Apo (a) isoforms predict risk for coronary heart disease. Atherosclerosis and Thrombosis 1992; 12:1214-26.

7. Költringer P, Jürgens G. A dominant role of lipoprotein (a) in the investigation and evaluation of parameters indicating the development of cervical atherosclerosis. Atherosclerosis 1985; 58:187-98.

8. Zenker G, Költringer P, Bone G, Niederkorn K, Pfeiffer K, Jürgens G. Lipoprotein (a) as a strong indicator for cerebrovascular disease. Stroke 1986; 17:942-5.

9. Hoff HF, Beck GJ, Skibinski CHI, Jürgens, G, O'Neil J, Kramer J, et al. Serum Lp(a) level as a predictor of vein graft stenosis after coronary artery bypass surgery in patients. Circulation 1988; 77:1238-44. 
10. Rosengren A, Wilhelmsen L, Eriksson E, Rissberg B, Wedel H. Lipoprotein (a) and coronary heart disease: a prospective case-control study in a general population of middle aged men. Br Med J 1990; 301:1248-51.

11. Ridker PM, Hennekens $\mathrm{CH}$, Stampfer MJ. A prospective study of lipoprotein (a) and the risk of myocardial infarction. J Am Med Ass 1993; 270:2195-9.

12. Jauhiainen $M$, Koskinen $P$, Ehnholm C. Lipoprotein (a) and coronary heart disease risk: a nested case-control study of the Helsinki heart study participants. Atherosclerosis 1991; 89:59-67.

13. Schumacher M, Keßler A, Meier A, Weigert S, Wood WG. Lipoprotein(a) concentrations in cord and capillary blood from newborns and in serum from in-patient children, adolescent and adults. Eur J Clin Chem Clin Biochem 1994; 32:341-7.

14. Scanu AM, Fless GM. Lipoprotein (a). Heterogeneity and biological relevance. J Clin Invest 1990; 85:1709-15.

15. Laurell CB. Quantitative estimation of proteins by electrophoresis in agarose gel containing antibodies. Anal Biochem $1966 ; 15: 45$.

16. Kostner GM, Gries M, Pometta M, Molinari E, Pichler E, Aicher $\mathrm{H}$, et al. Immunochemical determination of lipoprotein $\mathrm{Lp}(\mathrm{a})$ : comparison of Laurell electrophoresis and enzymelinked immunosorbent assay. Clin Chim Acta 1990; 188:187-92.

17. Albers JJ, Adolphson JL, Hazzard WR. Radioimmunoassay of human plasma Lp(a) lipoprotein. J Lipid Res 1977; 18:331-8.

18. Fless GM, Synder L, Scanu M. Enzyme-linked immunoassay for $L p(a)$. J Lipid Res 1989; 30:651-62.

19. Labeur C, Michiels G, Bury J, Usher DC, Rosseneu M. Lipoprotein (a) quantified by an enzyme-linked immunosorbent assay with monoclonal antibodies. Clin Chem 1989; 35:1380-4.

20. Abe A, Maeda S, Makino K. Enzyme linked immunosorbent assay of lipoprotein (a) in serum and cord blood. Clin Chim Acta 1988; 177:31-40.

21. Cazzolato G, Prakash G, Green S, Kostner GM. The determination of lipoprotein $\mathrm{Lp}(\mathrm{a})$ by rate end point nephelometry. Clin Chim Acta 1983; 135:203-8.
22. Gillery P, Arthuis P, Cuperlies C, Circaud R. Rate nephelometry assay of serum lipoprotein (a). Clin Chem 1993; 39:503 =8.

23. Jürgens G, Herrmann A, Aktuna D, Petek W. Dissociationenhanced lanthanide fluorescence immunoassay of lipoprotein (a) in serum. Clin Chem 1992; 28:853-9.

24. Schriewer H, Assmann G, Sandkamp M, Schulte H. The relationship of lipoprotein (a) to risk factors of coronary heart disease: initial results of the prospective epidemiological study on company employees in Westfalia. J Clin Chem Clin Biochem 1984; $22: 591-6$.

25. Hemmilä I. Lanthanides as probes for time-resolved fluorometric immunoassays. Scand J Clin Lab Invest 1988; 48:389-400.

26. Missler U, Gaida U, Wood WG. Development and evaluation of a time-resolved immunofluorometric assay for thyrotropin. Eur J Clin Chem Clin Biochem 1993; 31:389-93.

27. Sgoutas DS, Tuten T. Effect of freezing and thawing of serum on the immunoassay of lipoprotein(a). Clin Chem 1992; 38:1873-7.

28. Craig YW, Poulin SE, Forster NR, Neveux LM, Wald NJ, Ledue TB. Effect of sample storage on the assay of lipoprotein(a) by commercially available radioimmunodiffusion and enzyme-linked immunosorbent assay. Clin Chem 1992; 38:550-3.

29. Laemmli UK. Cleavage of structural proteins during the assembly of the head of bacteriophage $T_{4}$. Nature 1970; 227:680-5.

30. Passing $\mathrm{H}$, Bablok W. A new biometrical procedure for testing the equality of measurements from two different analytical methods. J Clin Chem Clin Biochem 1983; 21:709-20.

Dr. Ulrich Missler

Institut für Radiologie der

Medizinischen Universität zu Lübeck

Ratzeburger Allee 160

D-23538 Lübeck

Germany 